\title{
ФIHAHCOBE ПРАВО
}
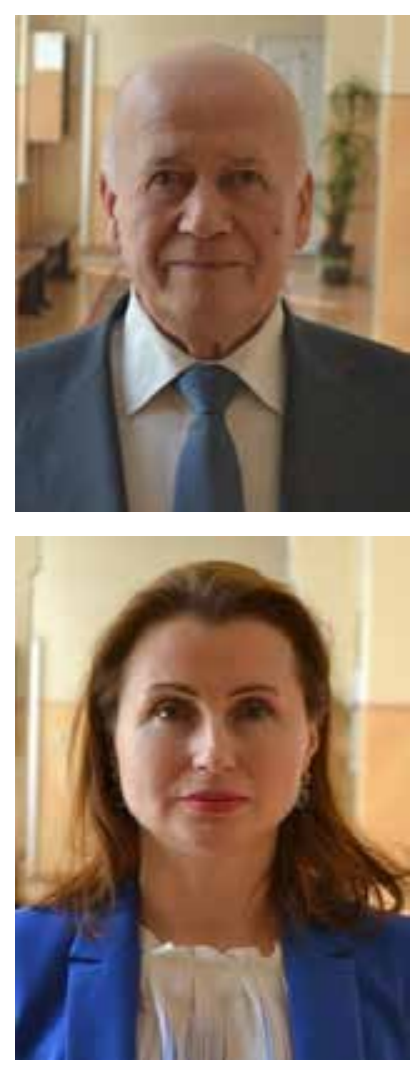

Петро Пацурківський, Аоктор юричичних наук, профресор, профресор кафредри публічного права Чернівецького національного університету імені Юрія Федьковича

ORCID: 0000-0001-5081-7842

\section{Руслана Гаврияюк,} Аокторка юричичних наук, Аоцентка, завімувачка кафредри публічного права Чернівецького національного університету імені Юрія Федьковича

ORCID: 0000-0001-6750-4340

DOI 10.32782/2306-9082/2021-44-4

УДК 347.73

\section{Дискусійні питання правової природи інституту одноразового (спеціального) добровільного декларування} фізичними особами належних їм активів та сплати одноразового збору до бюджсету

Постановка проблеми. Феномен податків і податкового права належить до найдавніших та найунікальніших явищ людської цивілізації. Ставши природним наслідком, продуктом певного рівня іiі зрілості, в подальшому вони трансформувалися в найважливіші засади суспільного розвитку. Історичний досвід переконує, що способом існування податків і податкового права є їхня перманентна змінюваність. На цю їхню особливість ще на початку XX ст. звернув увагу відомий вчений, юрист-фінансист 
I.X. Озеров, зазначивши, що «історія оподаткування - це історія боротьби уряду та суспільства. Держава створюе податки, суспільство вишукує способи їх уникнути; і доти, поки цей спосіб ще не знайдений, уряд користується створеною ним формою оподаткування; проте щойно скрута підкаже народу вихід, уряд знову повинен шукати новий спосіб розкладки» [1, с. 303].

Вже з другої половини ХХ ст. і до сьогодення держави стали ще більш винахідливими у створенні найрізноманітніших форм акумуляції коштів у публічні фонди фінансових ресурсів. Поряд з іншими чинниками до цього їх спонукала втрата монополії держави на правотворчість, що суттєво ускладнило боротьбу держав за виживання. На цей феномен одним із перших звернув увагу відомий італійський вчений-правознавець Ф. Галгано, зазначивши, що «державна монополія на правотворчість поступилася місцем іншій системі, яка допускає за межами закону інші, недержавні джерела права, джерела права подвійного глобального характеру: за сферою його застосування, оскільки воно повинно застосовуватися поза будь-якими територіальними кордонами, та за способом його утворення, оскільки воно може створюватися в найрізноманітніших куточках планети» [2, с. 31].

В останній третині XX ст. держави втратили і монопольне право на оподаткування, на що резонно звернув увагу Д.О. Гетманцев. Зокрема, наразі йдеться передусім про міжнародне екологічне оподаткування, але сфера конкурентного 3 іншими суб'єктами права оподаткування має очевидну тенденцію до розширення. За цих умов, резюмує Д.О. Гетманцев, «деякі держави вже стали на правильний шлях розвитку податкових відносин шляхом запровадження нового формату взаємин між державою і платником податків...» [3, с. 466]. Суттю цих інновацій, за словами дослідника,
$€$ «зміщення акцентів 3 узвичаєних взаємин «влада - підпорядкування» на відносини, які передбачають якщо не рівність сторін, то хоча б правильний баланс правовідносин» [3, с. 466].

Парадигмально змінені умови функціонування субстанційних держав, поява та утвердження інструментальних держав призводять до появи нетрадиційних форм акумулювання грошових коштів у державні фонди фінансових ресурсів, правова природа яких нерідко суттєво відрізняється від класично податкової природи. Незмінною залишається тільки основоположна мета оподаткування, яка чи не найбільш відверто була сформульована ще творцями Конституції США. Зокрема, у п. 1 розділу 8 цієї Конституції йдеться про таке: «Конгрес має право вводити і справляти податки, мита, збори й акцизи для того, щоб сплачувати борг i забезпечувати спільну оборону та загальне благополуччя Сполучених Штатів» [4, с. 809]. Інакше кажучи, йдеться про акумуляцію коштів у публічні фонди фінансових ресурсів.

Однією 3 найновіших нетрадиційних форм акумулювання грошових коштів у державні фонди фінансових ресурсів в Україні вже стало одноразове (спеціальне) добровільне декларування фізичними особами належних їм активів та сплата ними одноразового збору до бюджету, запроваджені Законом України «Про внесення змін до Податкового кодексу України та інших законів України щодо стимулювання детінізації доходів та підвищення податкової культури громадян шляхом запровадження одноразового (спеціального) добровільного декларування фізичними особами належних їм активів та сплати одноразового збору до бюджету» від 15 червня 2021 p. № 1539-IX [5].

Ще у процесі розробки та прийняття цього Закону вітчизняне експертне середовище, передусім 
експерти-правознавці, частина правників-науковців, визначили таке одноразове (спеціальне) добровільне декларування фізичними особами належних їм активів та сплату одноразового збору до бюджету (далі - новий інститут права) як податкову амністію. Законодавець надав суперечливе офіційне визначення цього інституту права: як «одноразове (спеціальне) добровільне декларування фізичними особами належних їм активів» та як «одноразовий обов’язковий платіж, розмір якого самостійно розраховується декларантом із вартості належних йому активів, з урахуванням ставок такого збору державою» [5]. А метою цього нового правового інституту, відповідно до тлумачення законодавцем, $€$ «стимулювання детінізації доходів та підвищення податкової культури громадян» [5]. То якою є істинна природа цього правового інституту?

Мета дослідження полягає у з'ясуванні правової природи вищезазначеної групи правових норм та їхнього місця в системі права України.

За основу пізнавального інструментарію авторами статті взято формально-догматичний метод позитивістської традиції правопізнання та реалістичну феноменологію як один із базисних методів антропосоціокультурного підходу до пізнання права. Така строкатість, більше того, протилежність методологічних підходів до пізнання правової природи вищезазначеного інституту права України зумовлена як інноваційним характером цього інституту, так і відсутністю в нього достатньої кількості апріорних ознак, які б заздалегідь недвозначно вказували на його ймовірну правову природу.

Виклад основного матеріалу. Як виходить із назви вищезазначеного Закону України, вітчизняний законодавець відніс групу юридичних норм, що лягли в основу цього нового інституту права, до інститутів податкового права. Природно з'ясувати, чи не запроваджується цією групою норм новий податок в Україні? Адже, як резонно зауважує М.П. Кучерявенко, «характеристика змісту податку, його правової природи дуже часто припускає не тільки якусь закінчену й коротку дефініцію, але й з'ясування, дослідження ознак, що виражають зміст цього поняття» [6, с. 119].

До аксіом податкового права належить твердження, що «податок являє собою вид платежу, закріплений актом державної влади» [6, с. 119]. Група правових норм, що досліджується нами, безперечно, має таку ознаку. Проте ще однієї атрибутивної ознаки податку - його обов'язкового характеру - новий інститут права не має у класичній формі, адже одноразове (спеціальне) декларування фізичними особами належних їм активів віднесено законодавцем до правочинів, що здійснюються на добровільних засадах, а обов'язковим є лише «збір 3 одноразового (спеціального) добровільного декларування» [5]. Згідно 3 юридичною конструкцією цього збору, визначеною законодавцем України, його розмір «самостійно розраховується декларантом із вартості належних йому активів з урахуванням ставок такого збору... та відображається ним в одноразовій (спеціальній) добровільній декларації» [5]. Проте законодавець передбачив, що подана фізичною особою «одноразова (спеціальна) добровільна декларація підлягає... камеральній перевірці, яку центральний орган виконавчої влади, що реалізує державну податкову політику, проводить впродовж 60 календарних днів, що настають за днем подання йому відповідної декларації» [5].

У Законі України «Про внесення змін до Податкового кодексу України та інших законів України щодо стимулювання детінізації доходів та підвищення податкової культури громадян шляхом запровадження 
одноразового (спеціального) добровільного декларування фізичними особами належних їм активів та сплати одноразового збору до бюджету» від 15 червня 2021 р. № 1539-IX встановлено не тільки суб'єкта цього декларування - фізичну особу, але й цілу низку інших елементів, зазвичай властивих податку: об'єкт збору; базу для нарахування збору з одноразового (спеціального) добровільного декларування; ставку та суму збору тощо.

Зокрема, Верховною Радою України до об'єктів одноразового (спеціального) добровільного декларування фізичною особою віднесено «ii активи, розміщені на території України та/або за їі межами, якщо такі активи фізичної особи були одержані (набуті) такою фізичною особою за рахунок доходів, що підлягали в момент їх нарахування (отримання) оподаткуванню в Україні та з яких не були сплачені або сплачені не в повному обсязі податки і збори, відповідно до вимог законодавства з питань оподаткування та/або міжнародних договорів, згода на обов'язковість яких надана Верховною Радою України, та/або які не були задекларовані в порушення податкового та валютного законодавства, контроль за дотриманням якого покладено на контролюючі органи, впродовж будьякого з податкових періодів, що мали місце до 1 січня 2021 р.» [5].

Базу для нарахування збору з одноразового (спеціального) добровільного декларування, як передбачено законодавцем, фізична особа-декларант визначає самостійно в національній валюті, відповідно до методики, що міститься у ст. 7 вищезазначеного Закону України. Також істотними особливостями визначення бази для нарахування збору 3 одноразового (спеціального) добровільного декларування є те, що фізична особа-декларант зобов'язана додати до одноразової (спеціальної) добровільної декларації копії документів, які підтверджують вартість об’єктів декларування, якщо місцезнаходження (реєстрація) активу фізичної особи розташоване за межами України та/або в разі декларування валютних цінностей, розміщених на рахунках у банках України. В разі місцезнаходження (реєстрації) об'єктів декларування активів фізичної особи в Україні декларант може додати копії документів, що підтверджують вартість об’єктів декларування [5]. Порівняльний аналіз бази для нарахування збору з одноразового (спеціального) добровільного декларування фізичною особою належних їй активів та бази для нарахування податку в класичному оподаткуванні переконує у кардинальних відмінностях між ними.

Ставки одноразового збору до бюджету, які належить сплатити фізичній особі-декларанту в разі декларування нею належних їй активів, визначені законодавцем України для кожної групи об'єктів одноразового (спеціального) добровільного декларування активів фізичних осіб: 5\% щодо валютних цінностей, розміщених на рахунках у банках в Україні з дотриманням чинного законодавства, та щодо права грошової вимоги до резидентів України; 9\% щодо валютних цінностей, розміщених на рахунках в іноземних банках або які зберігаються в іноземних фінансових установах, та щодо права грошової вимоги до нерезидентів України. «Як альтернативу, - зазначено у цьому Законі, - платник податків (але чи це дійсно платник податків? - П. П. та $P . \Gamma$.) може обрати ставку $11,5 \%$ зі сплатою податкового зобов'язання (чи це дійсно податкове зобов'язання? П. П. та $Р$. Г.) трьома рівними частинами щорічно; 2,5\% щодо номінальної вартості державних облігацій України 3 терміном обігу понад 365 днів без права дострокового погашення, придбаних декларантом у період з 1 вересня 2021 р. до 31 серпня 2022 р. до подання одноразової (спеціальної) 
добровільної декларації». В якості альтернативи у цьому випадку платник податків може обрати ставку $3 \%$ відсотки зі сплатою «податкового зобов'язання» трьома рівними частинами щорічно [5].

Сума збору з одноразового (спеціального) добровільного декларування щодо задекларованих об'єктів визначається фізичною особою-декларантом самостійно шляхом застосування до бази для нарахування збору з одноразового (спеціального) добровільного декларування методики, розробленої законодавцем, і вищезазначених ставок. Ці параметри одноразового збору до бюджету на підставі одноразового (спеціального) добровільного декларування фізичними особами належних ім активів також кардинально відрізняють його від аналогічних елементів класичного податку.

Цей одноразовий збір до бюджету не має нецільового характеру чи ознаку індивідуальної безвідплатності. Адже, відповідно до вищезазначеного Закону України, «сплата декларантом у повному обсязі суми збору з одноразового (спеціального) добровільного декларування, у тому числі донарахування грошового зобов'язання, у випадках, передбачених цим Законом, звільняє такого декларанта від відповідальності за порушення податкового та валютного законодавства, контроль за дотриманням якого покладено на контролюючі органи, та від обов'язку нарахування та сплати податків і зборів щодо доходів, які стали джерелом одержання (набуття) активів, зазначених таким декларантом в одноразовій (спеціальній) добровільній декларації (у межах складу і вартості активів, зазначених в одноразовій (спеціальній) добровільній декларації) як об’єкт i база для нарахування збору з одноразового (спеціального) добровільного декларування, що мали місце в будьякому з податкових періодів до 1 січня 2021 p.» [5].
I хоча ще деякі елементи одноразового збору із задекларованих фізичними особами належних їм активів до бюджету мають спільні якості 3 аналогічними елементами податку в класичному оподаткуванні, зокрема платіж вноситься у грошовій формі; він надходить до бюджету відповідного рівня, вищевикладеного достатньо для обгрунтування висновку про те, що одноразовий збір із задекларованих фізичними особами належних їм активів до бюджету за його правовою природою не може бути віднесений до класичних податків. Окрім вищевикладеного, цей платіж не відповідає атрибутивній вимозі п. 6.1 ст. 6 «Поняття податку і збору» Податкового кодексу України, згідно 3 яким «податком є обов'язковий, безумовний платіж до відповідного бюджету або на єдиний рахунок, що справляється з платників податку відповідно до цього Кодексу» [7]. Запроваджені Законом України від 15 червня 2021 р. № 1539-IX одноразове (спеціальне) декларування фізичними особами належних їм активів та сплата одноразового збору до бюджету суперечать також ст. 7, 8, 9 Податкового кодексу України. Тому неодноразова кваліфікація платежу як «податкового зобов'язання», а його платника - як «платника податку» в Законі України «Про внесення змін до Податкового кодексу України та інших законів України щодо стимулювання детінізації доходів та підвищення податкової культури громадян шляхом запровадження одноразового (спеціального) добровільного декларування фізичними особами належних їм активів та сплати одноразового збору до бюджету» є помилковою та не відповідає дійсній правовій природі цього платежу.

Водночас охарактеризовані нами вище властивості одноразового збору за наслідками одноразового (спеціального) добровільного декларування фізичними особами належних їм 
активів формально не суперечать п. 6.2 ст. 6 Податкового кодексу України: «Збором (платою, внеском) є обов'язковий платіж до відповідного бюджету або на єдиний рахунок, що справляється 3 платників зборів, 3 умовою отримання ними спеціальної вигоди, у тому числі внаслідок вчинення на користь таких осіб державними органами, органами місцевого самоврядування, іншими уповноваженими органами та особами юридично значимих дій» [7], проте суперечить змістовно ст. 8 і 9 Податкового кодексу України.

Звільнення фізичних осіб-декларантів за родовою ознакою від кримінальної та адміністративної відповідальності за несплату чи неповну сплату податків та інших обов’язкових платежів, звільнення їх від цих платежів, безумовно, належить до «юридично значимих дій». Але чи відповідає це задекларованій меті Закону - «стимулюванню детінізації доходів та підвищенню податкової культури громадян»? Адже фактично стимулюються протилежні цінності: тінізація доходів та нехтування податковою культурою як правовим феноменом. Чи намагався вітчизняний законодавець під час розробки та ухвалення вищезазначеного закону забезпечити розумний баланс між публічним інтересом суспільства та приватним інтересом неплатників податків і зборів? Прийняття ним Закону саме у чинній його редакції схиляє до негативної відповіді на це питання.

Чи правомірно розцінювати новий правовий інститут, який зводиться до запровадження одноразового (спеціального) добровільного декларування фізичними особами належних їм активів та сплати одноразового збору до бюджету, як інститут податкової амністії? Згідно з Законом України «Про застосування амністії в Україні» амністія - це «повне або часткове звільнення від відбування покарання осіб, визнаних винними у вчиненні кримінального правопорушення, або кримінальні справи стосовно яких розглянуті судами, але вироки стосовно цих осіб не набули законної сили» [8].

Податкова амністія, за аналогією, не може бути чимось іншим, ніж також повним або частковим звільненням від відбування покарання осіб, визнаних винними у вчиненні податкових правопорушень, або судові справи стосовно яких розглянуті судами, проте вироки чи інші рішення судів стосовно цих осіб не набрали законної сили. Чи $є$ умовою одноразового (спеціального) добровільного декларування фізичними особами належних їм активів та сплати ними одноразового збору до бюджету попереднє визнання цих осіб винними у скоєнні податкових правопорушень? Законодавець України дав негативну відповідь на це питання.

Загальновідомо, що однією з аксіом права є презумпція невинуватості особи. Відповідно до ст. 62 Конституції України «особа вважається невинуватою у вчиненні злочину (як, до речі, й іншого правопорушення П. П. та Р. Г.) і не може бути піддана кримінальному покаранню, доки іiі вину не буде доведено в законному порядку i встановлено обвинувальним вироком суду. Ніхто не зобов'язаний доводити свою невинуватість у вчиненні злочину. Обвинувачення не може грунтуватися на доказах, одержаних незаконним шляхом, а також на припущеннях. Всі сумніви щодо доведеності вини особи тлумачаться на iї користь» [9]. А відповідно до ч. 2 ст. 61 Конституції України «юридична відповідальність особи має індивідуальний характер» [9].

Виходячи 3 вищевикладеного, неправомірно застосовувати родове поняття «податкова амністія» до осіб, які не тільки не були визнані винними у вчиненні кримінального чи іншого правопорушення, але й не були віднесені в законному порядку до підозрюваних у вчиненні такого правопорушення. 
Тому поняття «податкова амністія» може бути обгрунтовано віднесене до поширених і навіть укорінених юридичних химер, але не реальних інститутів права України.

Отже, 3 пізнавальних позицій формально-догматичного підходу, який лежить в основі всієї юридичної конструкції Податкового кодексу України, відсутні достатні підстави для віднесення одноразового (спеціального) добровільного декларування фізичними особами належних їм активів та сплати одноразового збору до бюджету до податкової системи України в ії тлумаченні п. 6.3 Податкового кодексу України. Ймовірніше, навпаки, вищезазначений інститут права України претендує на роль «троянського коня» податкового права України, оскільки за більшістю своїх основних властивостей спрямований на підрив зсередини панівної в Україні парадигми податкових правовідносин як відносин ієрархічних, в основі яких лежить метод імперативних приписів. Основним недоліком формально-догматичного методу як інструменту з'ясування природи одноразового (спеціального) добровільного декларування фізичними особами належних їм активів та сплати одноразового збору до бюджету є те, що він виявився неспроможним забезпечити пізнання правової природи цього інституту в його цілісності та динаміці.

Такі можливості потенційно містить у собі феноменологічний метод. За визначенням відомого наукознавця Н.В. Мотрошилової, феноменологія як напрям філософії є вченням про феномени. Водночас вона являє собою суворо науковий метод безпосереднього угляду сутностей (природи) речей об'єктивного світу [10, с. 175 , 177]. Наприклад, німецький феноменолог початку XX ст. А. Райнах за допомогою реалістичної феноменології відкрив апріорні засади цивільного права. Вони виявились атрибутивно пов’язаними з індивідом як суб'єктом соціальної дії, творцем соціальних актів [11, с. 26].

Одноразове (спеціальне) добровільне декларування фізичними особами належних їм активів та сплата ними в разі такого декларування одноразового збору до бюджету також належать до роду соціальних актів, а їх творцями є фізичні особи, котрі діють на власний розсуд. Водночас між соціальними актами, які досліджував А. Райнах, та вищезазначеними соціальними актами існує принципова відмінність, оскільки перші належали до предмета цивільно-правового регулювання, яке передбачає необмежений перелік варіантів можливої поведінки суб'єкта права, а другі регулюються фінансово-правовими нормами 3 ïx вичерпним переліком варіантів можливої поведінки суб'єкта права.

Один із видів соціальних актів другого типу першим у науці фінансового права України всебічно дослідив ще 10 років тому Д.О. Гетманцев. Мова йде про фінансово-правове зобов'язання. Він переконливо довів, що юридична конструкція фінансово-правового зобов'язання $є$ взаємозв'язком суб'єктивних прав та юридичних обов'язків його сторін. Ця конструкція щоразу відзначається індивідуальним характером, а її реалізація спирається на силу державного примусу. Суб'єктами фінансово-правового зобов'язання, як показав Д.О. Гетманцев, можуть бути: держава безпосередньо чи в особі уповноважених органів, територіальні громади в особі органів місцевого самоврядування або органів місцевої влади, колективні суб'єкти та індивідуальні суб'єкти, в тому числі і фізичні особи [12, с. 287].

Д.О. Гетманцев у своєму монографічному дослідженні резюмував, що характерною рисою всього інституту фінансово-правового зобов'язання є не юридична рівність його суб'єктів між собою (про таку рівність не може 
бути й мови), а публічно-правова природа їх взаємозв'язку. Держава, закріплюючи в межах юридичної конструкції фінансово-правового зобов'язання взаємоузгоджені права та обов'язки його сторін, водночас позбавляє всі суб'єкти права самостійно змінювати волю держави, виходити за межі цієї юридичної конструкції [12, с. 288]. Не змінив Д.О. Гетманцев своїх поглядів на природу фінансово-правового зобов'язання і в подальших своїх дослідженнях [3, с. 497-498].

Саме такі властивості, як було продемонстровано вище, притаманні i групі якісно виокремлених норм, якими законодавець України врегулював одноразове (спеціальне) добровільне декларування фізичними особами належних їм активів та сплату ними одноразового збору до бюджету. Отже, за своєю природою цей інститут $€$ фінансово-правовим зобов'язанням фізичних осіб у сфері одноразового (спеціального) добровільного декларування ними належних їм активів та сплати одноразового збору до бюджету.
Висновки. Одноразовий збір до бюджету, що вноситься фізичними особами за наслідками одноразового (спеціального) добровільного декларування ними належних їм активів, відповідно до Закону України «Про внесення змін до Податкового кодексу України та інших законів України щодо стимулювання детінізації доходів та підвищення податкової культури громадян шляхом запровадження одноразового (спеціального) добровільного декларування фізичними особами належних їм активів та сплати одноразового збору до бюджету», не є ні податком, ні збором в їх тлумаченні Податковим кодексом України, а відповідні фізичні особи не є платниками ні податку, ні збору в їх вищезазначеному розумінні. За своєю природою відповідна група юридичних норм (інститут права) є фінансово-правовим зобов'язанням фізичних осіб у сфері одноразового (спеціального) добровільного декларування належних їм активів та сплати одноразового збору до бюджету.

\section{Список використаних джерел}

1. Озеров И.Х. Основы финансовой науки. Вып. 1. Москва, 1909. 544 с.

2. Галгано Ф. Объявленная революция. Правоведение. 2013. № 3. С. 11-33.

3. Гетманцев Д.А. Очерки философии налога. Харьков : Фолио, 2019. 526 с.

4. Конституции государств Америки / под ред. Т.Я. Хабриевой. Москва, 2006. Т. 1. Северная и Центральная Америка. 832 c.

5. Про внесення змін до Податкового кодексу України та інших законів України щодо стимулювання детінізації доходів та підвищення податкової культури громадян шляхом запровадження одноразового (спеціального) добровільного декларування фізичними особами належних їм активів та сплати одноразового збору до бюджету : Закон України від 15 червня 2021 р. № 1539-ІХ. Відомості Верховної Ради. 2021. № 34. Ст. 274.

6. Кучерявенко М.П. Податкове право України. Академічний курс : підручник. Київ : Правова єдність, 2008. 701 с.

7. Податковий кодекс України від 2 грудня 2010 р. № 2755-VI. Дата оновлення: 1 серпня 2021 p. URL: https://zakon.rada.gov.ua/laws/show/2755-17\#n10752.

8. Про застосування амністії в Україні : Закон України від 1 жовтня 1996 р. № 392/96-BP. Дата оновлення: 3 липня 2020 p. URL: https://zakon.rada.gov.ua/laws/ show/392/96-\%D0\%B2\%D1\%80\#Text.

9. Конституція України : Закон України від 28 червня 1996 р. № 254к/96-ВР. Дата оновлення: 1 січня 2020 p. URL: https://zakon.rada.gov.ua/laws/show/254\%D0\%BA/96$\%$ D0\%B2\%D1\%80\#Text. 
10. Мотрошилова Н.В. Феноменология. Новая философская энщиклопедия. Том четвертый. Т-Я. Москва : Мысль, 2010. 744 с.

11. Райнах А. Собрание сочинений. Москва : Дом интеллектуальной книги, 2001. 484 c.

12. Гетманцев Д.О. Фінансово-правове зобов'язання як окрема категорія фінансового права : монографія. Київ : Юрінком Інтер, 2011. 368 с.

Пацурківський П. С., Гаврилюк Р. О. Дискусійні питання правової природи інституту одноразового (спеціального) добровільного декларування фізичними особами належних ім активів та сплати одноразового збору до бюджету

У статті за допомогою формально-догматичного методу позитивістської традиції правопізнання та методу реалістичної феноменології як інструменту антропосоціокультурного підходу до пізнання права досліджуються деякі дискусійні питання правової природи інституту одноразового (спеціального) добровільного декларування фізичними особами належних їм активів та сплати ними одноразового збору до бюджету. Авторами статті така строкатість, більше того, навіть протилежність застосованих методологічних підходів до пізнання правової природи вищезазначеного інституту пояснюється як інноваційний характер цього інституту права, відсутність у нього достатньої кількості апріорних ознак, які б заздалегідь недвозначно вказували на його ймовірну правову природу. Обгрунтовано висновок, що одноразовий збір до бюджету, що вноситься фізичними особами в результаті одноразового (спеціального) добровільного декларування ними належних їм активів, відповідно до Закону України «Про внесення змін до Податкового кодексу України та інших законів України щодо стимулювання детінізації доходів та підвищення податкової культури громадян шляхом запровадження одноразового (спеціального) добровільного декларування фізичними особами належних їм активів та сплати одноразового збору до бюджету», не є ні податком, ні збором в їх тлумаченні Податковим кодексом України, а відповідні фізичні особи не є платниками ні податку, ні збору в їх вищезазначеному розумінні. Доведено, що хоч вищезазначений інститут права формально і не суперечить визначенню збору в його тлумаченні п. 6.2 ст. 6 Податкового кодексу України, він також не відповідає системному тлумаченню збору цим Кодексом. Не відповідає цей інститут права й юридичному феномену «амністія» в їі тлумаченні законодавцем України. Автори статті резюмують, що вищезазначена група юридичних норм (інститут права) за своєю природою є фінансово-правовим зобов'язанням фізичних осіб у сфері одноразового (спеціального) добровільного декларування належних їм активів та сплати одноразового збору до бюджету.

Ключові слова: податок, збір, одноразове (спеціальне) добровільне декларування фізичними особами належних їм активів та сплата одноразового збору до бюджету, Податковий кодекс України, фінансово-правове зобов’язання.

Пацуркивский П. С., Гаврилюк Р. А. Дискуссионные вопросы правовой природы института однократного (специального) добровольного декларирования физическими лицами принадлежащих им активов и уплаты одноразового сбора в бюджет

В статье при помощи формально-догматического метода позитивистской традиции правопознания и метода реалистической феноменологии как инструмента антропосоциокультурного подхода к познанию права исследуются некоторые дискуссионные вопросы правовой природы института однократного (специального) добровольного декларирования физическими лицами принадлежащих им активов и уплаты ими одноразового сбора в бюджет. Авторами статьи такая неоднородность, более того, даже противоположность примененных методологических подходов к познанию правовой природы вышеупомянутого института объясняется как инновационный характер этого института права, как отсутствие у него достаточного количества априорных признаков, которые бы заблаговременно недвусмысленно указывали на его вероятную правовую 
природу. Обосновано, что одноразовый сбор в бюджет, который вносится физическими лицами по результатам однократного (специального) добровольного декларирования ими своих активов в соответствии с Законом Украины «О внесении изменений в Налоговый кодекс Украины и другие законы Украины относительно стимулирования детенизации доходов и повышения налоговой культуры граждан путем введения одноразового (специального) добровольного декларирования физическими лицами принадлежащих им активов и уплаты одноразового сбора в бюджет», не является ни налогом, ни сбором в их понимании Налоговым кодексом Украины, а соответствующие физические лица не являются плательщиками ни налога, ни сбора в их вышеуказанном понимании. Доказано, что хотя вышеупомянутый институт права формально не противоречит определению сбора в его толковании п. 6.2 ст. 6 Налогового кодекса Украины, тем не менее, он также не соответствует системному толкованию сбора настоящим Кодексом. Не соответствует этот институт права и юридическому феномену «амнистия» в его толковании законодателем Украины. Авторы статьи резюмируют, что вышеупомянутая группа юридических норм (институт права) по своей природе является финансово-правовым обязательством физических лиц в сфере однократного (специального) добровольного декларирования принадлежащих им активов и уплаты одноразового сбора в бюджет.

Ключевые слова: налог, сбор, однократное (специальное) добровольное декларирование физическими лицами принадлежащих им активов и уплата одноразового сбора в бюджет, Налоговый кодекс Украины, финансово-правовое обязательство.

Patsurkivskyy P., Havrylyuk R. Discussion issues of the legal nature of the institution of one-time (special) voluntary declaration by individuals of their assets and payment of a one-time fee to the budget

The article uses the formal-dogmatic method of the positivist tradition of legal knowledge and the method of realistic phenomenology as a tool of anthroposociocultural approach to knowledge of law to examine some discussion issues of the legal nature of the institution of one-time (special) voluntary declaration of assets and payment by individuals. The authors of this article explain such diversity, moreover, even the opposite of their methodological approaches to understanding the legal nature of the above-mentioned institute, both by the innovative nature of this institute of law and its lack of sufficient a priori features that would unequivocally indicate its probable legal nature. The conclusion is substantiated that a one-time fee to the budget, which is made by individuals as a result of a one-time (special) voluntary declaration of their assets by them in accordance with the Law of Ukraine "On Amendments to the Tax Code of Ukraine and other laws of Ukraine regarding the stimulation of income detinization and an increase in the tax culture of citizens by introducing a onetime (special) voluntary declaration by individuals of their assets and paying a one-time fee to the budget" is neither a tax nor a fee in their understanding of the Tax Code of Ukraine, and the respective individuals are not payers of either tax or collection in their above sense. It has been proved that although the aforementioned institution of law does not formally contradict the definition of a levy as interpreted by paragraph 6.2 of Article 6 of the Tax Code of Ukraine, nevertheless, it also does not correspond to the systemic interpretation of levy by this Code. This institution of law does not correspond to the legal phenomenon of "amnesty" as interpreted by the Ukrainian legislator. The authors of the article summarize that the aforementioned group of legal norms (institution of law) is by its nature a financial and legal obligation of individuals in the field of one-time (special) voluntary declaration of their assets and payment of a one-time fee to the budget.

Key words: tax, collection, one-time (special) voluntary declaration by individuals of their assets and payment of a one-time fee to the budget, Tax Code of Ukraine, financial and legal obligation. 